\title{
Kompetensi Kepribadian Widyaiswara dan Pengaruhnya terhadap Hasil Belajar Peserta Diklat Prajabatan CPNS K1/K2
}

\author{
Tarmujianto \\ Widyaiswara BPSDM Provinsi DKI Jakarta \\ tarmujiant@yahoo.co.id
}

\begin{abstract}
Abstrak
Penelitian ini bertujuan untuk mengetahui dan menganalisis pengaruh kompetensi kepribadian Widyaiswara terhadap hasil belajar. Subyek penelitian ini adalah peserta diklat prajabatan K1/K2 golongan III DKI Jakarta tahun 2019 yang berjumlah 166 peserta. Dalam pengambilan sampel menggunakan rumus Slovin dengan derajat kepercayaan 95\%. Desain penelitian yang digunakan dalam penelitian ini adalah penelitian korelasional. Teknik pengumpulan data melalui angket dan dokumentasi. Berdasarkan hasil penelitian diketahui bahwa kompetensi kerpibadian widyaiswara berpengaruh terhadap hasil belajar peserta diklat prajabatan. Hal ini terlihat dari hasil analisis data di mana nilai koefisien determinasi sebesar 0,307 yang menginformasikan bahwa kompetensi kepribadian widyaiswara memberikan kontribusi sebesar $30,7 \%$ dari hasil belajar, sedangkan sisanya dipegaruhi oleh variabel lain yang tidak menjadi fokus dalam penelitian ini. Sedangkan nilai koefisien regresi sebesar 3,076 menginformasikan adanya pengaruh yang positif dari kompetensi kepribadian widyaiswara terhadap hasil belajar. Artinya semakin baik kompetensi kepribadian widyaiswara maka hasil belajar akan semakin tinggi, begitu pula sebaliknya. Nilai koefisien ini juga mengartikan hasil belajar akan meningkat sebesar 3,076 pada setiap kenaikan satu-satuan dari kompetensi kepribadian widyaiswara.
\end{abstract}

Kata kunci: hasil belajar, kompetensi kepribadian, widyaiswara.

Dikirim: 27 Juli 2020

Direvisi: 14 Agustus 2020

Diterima: 14 November 2020

Identitas Artikel:

Tarmujianto, T. (2021). Kompetensi Kepribadian Widyaiswara dan Pengaruhnya terhadap Hasil Belajar Peserta Diklat Prajabatan CPNS K1/K2. Jurnal Ilmu Pendidikan (JIP) STKIP Kusuma Negara, 12(2), 99-110.

\section{PENDAHULUAN}

Dalam kurun waktu saat ini yang lebih dikenal dengan sebutan era digital 4.0 di mana semua sendi kehidupan manusia dihadapkan pada situasi yang serba cepat serta serba instan, menjadikan semua bentuk pelayanan kepada masyarakat sebagai pelanggan pelayanan harus juga juga menyesuaikan perkembangan zamannya. Termasuk didalamnya lembaga pendidikan seperti BPSDM Provinsi DKI Jakarta sebagai penyelenggara kegiatan pendidikan, pengajaran dan pelatihan (Dikjartih) bagi calon pegawai negeri sipil dilingkungan pemerintah provinsi DKI Jakarta. Di dalam proses Dikjartih yang melibatkan widyaiswara dalam proses pembelajarannya dan merupakan faktor utama suatu proses kediklatan dituntut untuk serba tahu dan tidak boleh ketinggalan zaman.

Pendidikan memiliki peranan yang sangat penting dalam mencerdaskan kehidupan masyarakat. Maka dari itu, pendidikan menuntut orang-orang yang terlibat didalamnya untuk bekerja sama secara total, memiliki rasa tanggung jawab 
dan loyalitas yang tinggi dalam meningkatkan mutu pendidikan. Widyaiswara merupakan salah satu komponen dalam proses pendidikan dan pelatihan, yang ikut berperan dalam usaha pembentukan sumber daya manusia para calon aparatur sipil negara, sehingga sangat menentukan keberhasilan peserta diklat, terutama dalam kaitannya dengan proses belajar mengajar.

Tujuan Diklat Prajabatan CPNS Golongan III yang diangkat dari tenaga honorer K1/K2 sebagaimana yang dimaksud dalam Peraturan Kepala LAN-RI. No. 10 Tahun 2015 diselenggarakan untuk membentuk CPNS yang memiliki pengetahuan dan wawasan sebagai pelayan masyarakat yang baik. Adapun sasarannya adalah terwujudnya CPNS yang dapat memberikan pelayanan yang baik kepada masyarakat.

Namun pola Dikjartih yang mengabaikan pendidikan kepribadian atau karakter, bisa jadi akan membuat suatu proses kediklatan itu hampa. Karena ilmu pengetahuan dalam bentuk kognitif di masa sekarang, bisa dicari melalui internet atau internet of thing. Sedangkan kemampuan afektif, berupa sikap atau perilaku musti memerlukan sosok yang akan dijadikan tauladan atau panutan. Dalam hal ini peranan widyaiswara dalam membentuk watak, karakter atau kepribadian peserta diklat sangat diperlukan.

Untuk mewujudkan keberhasilan proses pembelajaran dalam suatu kediklatan, seorang widyaiswara tentunya dituntut untuk memiliki standar kompetensi, yakni kemampuan minimal yang secara umum dimiliki oleh seorang widyaiswara dalam melaksanakan tugas, tanggung jawab dan wewenangnya untuk mendidik, mengajar, dan/atau melatih PNS. Standar Kompetensi widyaiswara terdiri atas: kompetensi pengelolaan pembelajaran, kompetensi kepribadian, kompetensi sosial, dan kompetensi substantif.

Kompetensi merupakan kumpulan kemampuan seseorang yang secara dinamis menunjukkan kualitas intelektual, sikap mental dan skill seseorang. Kompetensi merupakan modal dasar yang harus dikuasai seorang untuk dapat melaksanakan pekerjaan atau profesinya sesuai dengan tugas dan tanggung jawab yang dibebankan kepadanya.

Menurut Spencer \& Spencer (dalam Moeheriono, 2012), kompetensi adalah karakteristik yang mendasari seseorang berkaitan dengan efektivitas kinerja individu dalam pekerjaannya atau karakteristik individu yang memiliki hubungan kausal atau sebagai sebab akibat dengan kriteria yang dijadikan acuan, efektif atau berkinerja prima superior ditempat kerja pada situasi tertentu. Sebagaimana Uno (2008) berpendapat bahwa kompetensi pendidik adalah salah satu faktor yang mempengaruhi tercapainya suatu tujuan pembelajaran dan pendidikan di sekolah, namun kompetensi tidak berdiri sendiri, karena dipengaruhi oleh latar belakang pendidikan, pengalaman dan lamanya seseorang mengajar.

Menurut Arjita (2019) tidak semua variabel di kompetensi widyaiswara mempengaruhi prestasi peserta diklat. Kompetensi yang mempunyai pengaruh langsung adalah kompetensi sistematika penyajian, kemampuan penyajian, cara menjawab pertanyaan dari peserta. Kompetensi kepribadian dan kompetensi sosial tidak bepengaruh terhadap prestasi peserta. Sehingga dalam penelitian ini, variabel kompetensi widyaiswara dibatasi hanya untuk menguji pengaruh kompetensi kepribadiannya saja.

Kompetensi kepribadian adalah kemampuan kepribadian yang mantap, berakhlak mulia, arif, dan berwibawa serta menjadi teladan peserta diklat. Mansing 
(2018) menyatakan bahwa kepribadian guru PAI merupakan cermin, baik atau tidaknya akhlak seorang siswa dan di lain sisi, kepribadian guru PAI ataupun guru pada umumnya yang baik, bersahabat, sejuk dan ramah dalam proses interaksi dengan siswa, baik dalam kelas maupun secara umum dalam lingkungan sekolah dapat meningkatkan antusisme dan kesenangan siswa dalam belajar yang dapat berimplikasi pada penentuan hasil belajar siswa.

Dalam penjelasan UU No. 14 Tahun 2005 tentang Guru dan Dosen dinyatakan bahwa yang dimaksud dengan kompetensi kepribadian adalah kemampuan kepribadian yang mantap, berakhlak mulia, arif, dan berwibawa serta menjadi teladan peserta didik. Dalam Peraturan Kepala LAN No. 5 Tahun 2008 dinyatakan bahwa kompetensi kepribadian adalah kemampuan yang harus dimiliki Widyaiswara mengenai tingkah laku dalam melaksanakan tugas jabatannya yang dapat diamati dan dijadikan teladan bagi peserta pelatihan.

Dalam PermenPAN-RB No. 22 Tahun 2014, Widyaiswara adalah PNS yang diangkat sebagai pejabat fungsional dengan tugas, tanggung jawab, wewenang, dan hak untuk melakukan kegiatan Dikjartih PNS, Evaluasi dan Pengembangan Diklat pada Lembaga Diklat Pemerintah. Dikjartih adalah proses belajar mengajar dalam Diklat baik secara klasikal dan/atau non klasikal.

Widyaiswara merupakan Profesi yang mulia dan menjadi ujung tombak pembinaan SDM aparat Pemerintah. Widyaiswara secara harfiah artinya adalah Pembawa Kebenaran (atau suara yang baik, dari kata Widya = Baik, dan Iswara = Suara), sehingga diharapkan Widyaiswara dapat menjadi suara bagi para PNS, mengajarkan nilai-nilai luhur yang harus dimiliki seorang PNS, agar menjadi PNS yang profesional, jujur, dan berakhlak mulia.

Sebelum menjadikan dirinya sebagai pembawa kebenaran, tentunya seorang widyaiswara harus mempraktikannya terlebih dahulu di depan para peserta yang menjadi tanggung jawabnya dalam proses Dikjartih. Hal ini sejalan dengan penelitian Ni'mah (2014) yang menyatakan berjalannya proses pendidikan berkat adanya guru, dengan melihat hal semacam itu guru mengandung arti pelayanan yang luhur. Baik di pendidikan formal maupun non formal posisi guru sangat dibutuhkan, oleh sebabnya kepribadian seorang guru merupakan hal yang sangat penting.

Widyaiswara dapat di identikan sebagai ujung tombak dari diklat yang dilaksanakan, sebab secara langsung berupaya memfasilitasi, membangun, memberdayakan, dan memotivasi peserta diklat agar mencapai tingkat kompetensi sesuai dengan potensi yang dimilikinya. Jika dikaitkan dengan kompetensi widyaiswara, disinilah pentingnya kompetensi kepribadian secara implementatif. Kepribadian yang mantap, stabil, arif dan berujung sebagai teladan harus terwujud bahwa widyaiswara menjadi sosok yang dipercaya dan diteladani oleh peserta diklat (Hamzah, 2017).

Oleh karena itu, kompetensi kepribadian widyaiswara yang diimplementasikan dengan baik dalam proses pendidikan pengajaran dan pelatihan atau Dikjartih, akan memberikan dampak terhadap hasil belajar peserta diklat. Hal ini sejalan dengan hasil penelitian yang dilakukan oleh Sumantri, Abdullah \& Nurlaila (2019) yang menyatakan bahwa ada pengaruh yang signifikan antara kompetensi kepribadian guru terhadap prestasi belajar siswa di MTs Ar-Riyadh 13 Ulu Palembang. Sedangkan menurut Pitra (2019) dalam penelitiannya menyimpulkan bahwa 
terdapat pengaruh kompetensi kepribadian Guru terhadap hasil belajar PAI siswa kelas VIII SMPN 02 Seluma.

Hasil belajar merupakan tingkat penguasaan yang dicapai oleh siswa dalam mengikuti program belajar mengajar, sesuai dengan tujuan yang ditetapkan. Menurut Sartika, Dahlan \& Waspada (2018) dalam penelitiannya menyatakan hasil belajar siswa mencerminkan kemampuan dan perkembangan sekaligus tingkat keberhasilan pendidikan. Menurut Dimyati \& Mudjiono (2018: 4) bahwa yang dimaksud dengan hasil belajar merupakan hasil dari suatu interaksi tindak belajar dan tindak mengajar. Dari sisi guru, tindak mengajar diakhiri dengan proses evaluasi belajar. Dari sisi siswa, hasil belajar merupakan berakhirnya penggal dan puncak proses belajar.

Hasil belajar adalah perubahan tingkah laku ke arah yang lebih baik yang meliputi aspek kognitif, afektif, dan psikomotorik sebagai hasil pengalaman belajar seseorang. Kecakapan atau kemampuan sebagai hasil belajar memungkinkan seseorang mampu melakukan suatu perbuatan yang tidak dapat dilakukan sebelumnya (Sutopo, 2019).

Dalam penelitian ini, yang dimaksud dengan hasil belajar, dibatasi pada hasil belajar dalam ranah kognitif saja yang terlihat dari hasil test tertulis atau evaluasi yang dilakukan oleh penyelenggara pada akhir kegiatan pelatihan untuk mengukur pemahaman peserta terhadap materi yang telah diterima selama pelatihan berlangsung. Untuk data hasil belajar dalam penelitian ini adalah hasil evaluasi peserta diklat prajabatan K1/K2 CPNS golongan III yang telah terdokumentasikan oleh penyelengggara diklat yaitu BPSDM Provinsi DKI Jakarta. Rata-rata dari hasil belajar setiap angkatan, bisa dilihat dari Gambar 1.

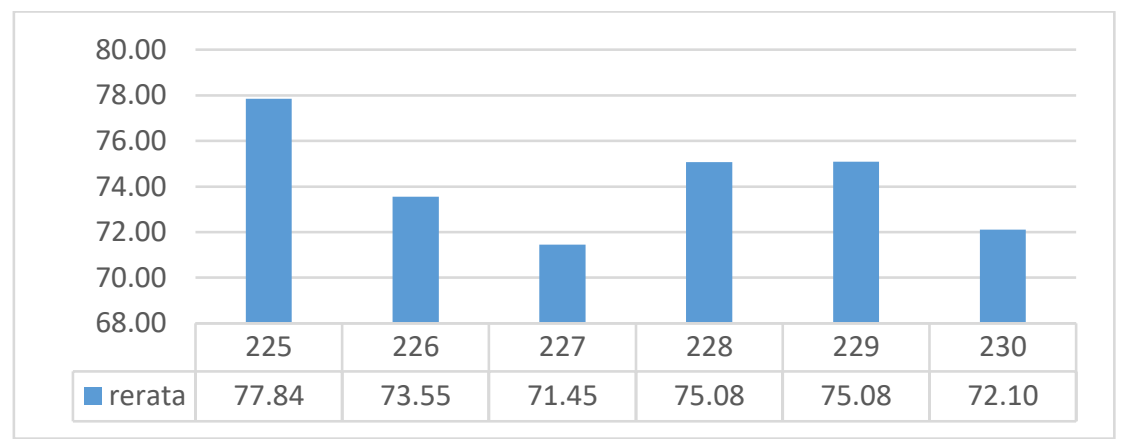

Gambar 1. Rata-rata Nilai Evaluasi

Dari data Gambar 1, menunjukan bahwa nilai hasil evaluasi akhir untuk setiap angkatan masih dalam kategori cukup memuaskan. Berdasarkan uraian di atas, hipotesis yang diajukan dalam penelitian ini adalah ada pengaruh kompetensi kepribadian widyaiswara terhadap hasil belajar peserta diklat prajabatan $\mathrm{K} 1 / \mathrm{K} 2$ CPNS golongan III yang diselenggarakan oleh BPSDM Provinsi DKI Jakarta.

\section{METODE PENELITIAN}

Desain penelitian yang digunakan dalam penelitian ini adalah penelitian korelasional (correlational research). Penelitian korelasional untuk mengetahui pengaruh kompetensi kepribadian widyaiswara terhadap hasil belajar berdasarkan koefisien korelasi. Hubungan korelatif mengacu pada kecenderungan bahwa variasi 
suatu variabel diikuti oleh variasi variabel yang lain dan dengan demikian dalam rancangan korelasional peneliti melibatkan dua variabel yakni variabel bebas (independen) dan variabel terikat (dependen).

Tabel 1. Data dan Sumber Data Penelitian

\begin{tabular}{ll}
\hline \multicolumn{1}{c}{ Data } & \multicolumn{1}{c}{ Sumber Data } \\
\hline Kompetensi Kepribadian Widyaiswara & Peserta latsar CPNS (responden) \\
\hline Hasil Belajar & Laporan dari Penyelenggara \\
\hline
\end{tabular}

Data hasil belajar yang diperoleh dari laporan penyelenggara mempermudah jangkauan peneliti untuk mengumpulkan data penelitian serta sudah terujinya tingkat validitas dan reliabilitasnya, sehingga mempercepat proses pengolahan data untuk bisa diambil kesimpulan yang bisa diandalkan.

Populasi dalam penelitian ini adalah seluruh peserta diklat prajabatan K1/K2 CPNS golongan III tahun 2019 yang berjumlah 166 peserta. Populasi adalah keseluruhan subjek penelitian (Arikunto, 2013: 173). Adapun teknik sampling yang digunakan adalah probability sampling. Dalam teknik ini, setiap anggota populasi mendapat peluang yang sama untuk dipilih menjadi sampel dengan cara simple random sampling. Dikatakan simpel (sederhana) karena pengambilan anggota sampel dari populasi dilakukan secara acak tanpa mempehatikan strata yang ada dalam populasi itu. Cara demikian dilakukan bila anggota populasi dianggap homogen (Sugiyono, 2017: 82).

Tabel 2. Jumlah Peserta Diklat Prajabatan K1/K2 CPNS
\begin{tabular}{cc} 
Golongan III Tahun 2019 \\
\hline Angkatan & Jumlah Peserta \\
\hline 225 & 30 \\
226 & 30 \\
227 & 30 \\
228 & 30 \\
229 & 30 \\
230 & 16 \\
\hline Jumlah Total & 166 \\
\hline
\end{tabular}

Dalam penelitian ini, pengambilan sampel menggunakan rumus Slovin, dengan derajat kepercayaan 95\%, maka tingkat kesalahan adalah 5\%. Sehingga peneliti dapat menentukan batas minimal sampel yang dapat memenuhi syarat margin of error 5\% dengan memasukkan margin of error tersebut ke dalam formula atau rumus Slovin $n=N /\left(1+\left(N \times e^{2}\right)\right) ; \quad$ sehingga $n=166 /\left(1+\left(166 \times 0,05^{2}\right)\right)$; $n=166 /(1+(166 \times 0,0025)) ; n=166 /(1+0,415) ; n=166 / 1,415 ; n=117,3145$. Dibulatkan menjadi $n=120$ peserta.

\section{Metode Pengumpulan Data}

Peneliti memberikan kuesioner kepada peserta diklat prajabatan berkaitan dengan kompetensi kepribadian widyaiswara. Setiap jawaban responden akan diberi skor sehingga memudahkan peneliti dalam mengelola hasil penelitian yang berupa data kuantitatif. Skala skor yang dipergunakan adalah sekala skor likert dengan kriteria 1 - Sangat Tidak Setuju (STS); 2 - Tidak Setuju (TS); 3 - Kurang Setuju (KS); 4 Setuju (S); dan 5 - Sangat Setuju (SS). Adapun daftar pernyataan indikator 
kompetensi kepribadian widyaiswara sebagai instrumen dalam penelitian ini adalah sebagai berikut.

Tabel 3. Indikator Kompetensi Kepribadian Widyaiswara

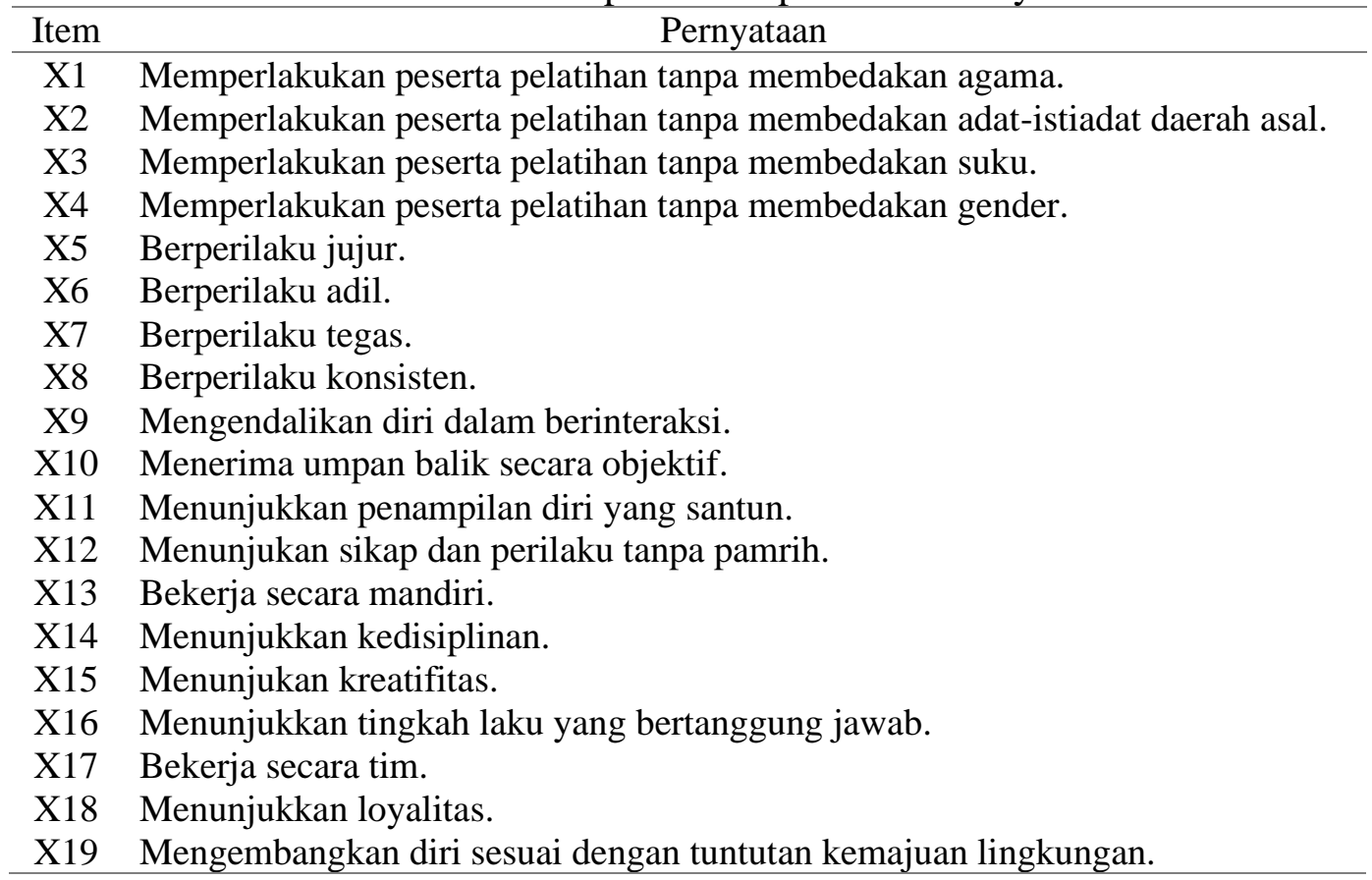

Sumber: Peraturan Kepala LAN No. 5 Tahun 2008

Indikator kompetensi kepribadian widyaiswara tersebut di atas merupakan pengembangan dari indikator kompetensi kepribadian widyaiswara yang tercantum dalam Peraturan Kepala LAN No. 5 Tahun 2008, di mana tercantum untuk instrumen standar kompetensi kepribadian terdiri dari sub kompetensi yakni menampilkan pribadi yang diteladani terdiri dari item pernyataan 1-10 dan melaksanakan kode etik dan menunjukkan etos kerja sebagai widyaiswara yang profesional terdiri item pernyataan 11-19.

Selanjutnya data yang sudah terkumpul dilakukan uji validitas dan realibilitas dengan menggunakan bantuan komputer SPSS versi 23 for windows. Sebuah instrument dikatakan valid apabila mampu mengukur apa yang kita inginkan dan dapat mengungkap data dari variabel yang diteliti secara tepat. Sugiyono (2017: 121) mengatakan bahwa Instrumen yang valid berarti alat ukur yang digunakan untuk mendapatkan data (mengukur) itu valid. Instrument dikatakan valid apabila memiliki $r>0,361$. Semua item yang sudah dinyatakan valid pada tahap uji validitas, kemudian diuji kehandalannya dengan menggunakan uji reliabilitas.

Suatu instrumen harus reliabel. Artinya, instrumen tersebut cukup baik hingga mampu mengungkap data yang bisa dipercaya. Instrumen dikatakan reliabel jika nilai cronbach's alpha lebih besar 0,60.

Tabel 4. Hasil Uji Reliabilitas

\begin{tabular}{rrr}
\hline \multicolumn{3}{c}{ Reliability Statistics } \\
Cronbach's Alpha & n of Items \\
& Based on Standardized Items \\
\hline, 976 &, 977 & 19 \\
\hline
\end{tabular}


Hasil uji reliabilitas diperoleh nilai cronbach's alpha pada variabel di atas yaitu 0,976 dan menunjukkan bahwa cronbach's alpha lebih dari 0,60 dan dapat dikatakan instrument untuk mengukur variabel penelitian ini, reliabel.

\section{HASIL DAN PEMBAHASAN}

Kualitas widyaiswara yang baik diharapkan dapat mendukung kualitas suatu diklat itu sendiri baik dari segi proses pembelajaran, kepribadian widyaiswara, serta hasil belajarnya. Kompetensi kepribadian widyaiswara sebagaimana tercantum dalam Peraturan Kepala LAN No. 5 Tahun 2008 mencakup widyaiswara harus menampilkan pribadi yang diteladani dan melaksanakan kode etik dan menunjukkan etos kerja sebagai widyaiswara yang profesional guna menunjang keberhasilan suatu diklat sesuai dengan harapan yang dibuktikan dengan hasil belajar atau outputnya.

\section{Hasil}

Untuk mengetahui sejauhmana pengaruh kompetensi kepribadian widyaiswara terhadap hasil belajar peserta diklat prajabatan $\mathrm{K} 1 / \mathrm{K} 2$ golongan III digunakan kuesioner yang kemudian disebar kepada seluruh peserta diklat prajabatan secara acak dan hasil perolehan kuesioner tersebut dianalisis agar dapat dideskripsikan.

Tabel 5. Statistik Deskriptif Kompetensi Kepribadian Widyaiswara

\begin{tabular}{|c|c|c|}
\hline \multicolumn{3}{|c|}{ Kompetensi Kepribadian } \\
\hline \multirow[t]{2}{*}{$n$} & Valid & 120 \\
\hline & Missing & 0 \\
\hline & & 82,4000 \\
\hline & & 91,0000 \\
\hline & & 95,00 \\
\hline & viation & 17,16279 \\
\hline & & 55,00 \\
\hline & & 40,00 \\
\hline & & 95,00 \\
\hline $\mathrm{Su}$ & & 9888,00 \\
\hline
\end{tabular}

Dari Tabel 5 dapat diketahui bahwa rata-rata sebesar 82,4, median 91, modus 95, dan standar deviasi 17,16. Skor tertinggi yang diperoleh adalah 95, sedangkan skor terendah adalah 40. Dilihat dari nilai mean sebesar 82,4 menginformasikan bahwa penilaian rentang sikap peserta terhadap kompetensi kepribadia widyaiswara dalam taraf yang tinggi.

Berdasarkan Tabel 6 diperoleh nilai korelasi 0,554 (koefisien mendekati angka 1), maka dapat disimpulkan bahwa hubungan antara kompetensi kepribadian widyaiswara dan hasil belajar memiliki korelasi yang kuat. Tanda bintang dua menunjukkan bahwa korelasi signifikan pada level 0,05. Angka koefisien positif menunjukkan hubungan positif, yaitu jika kompetensi meningkat maka hasil belajar juga akan meningkat. Nilai signifikansi yang didapat adalah 0,000 nilai tersebut kurang dari 0,05 , maka terjadi hubungan yang signifikan antara variabel kompetensi kepribadian widyaiswara dengan variabel hasil belajar. 
Tabel 6. Hasil Uji Korelasi Sederhana Correlations

\begin{tabular}{llrr}
\hline & & Hasil Belajar & $\begin{array}{r}\text { Kompetensi } \\
\text { Kepribadian }\end{array}$ \\
\hline Hasil Belajar & $\begin{array}{l}\text { Pearson Correlation } \\
\text { Sig. (2-tailed) }\end{array}$ & 1 &, $554^{* *}$ \\
& $n$ & 120 &, 000 \\
Kompetensi & Pearson Correlation &, $554^{* *}$ & 120 \\
Kepribadian & Sig. (2-tailed) &, 000 & 1 \\
& $n$ & 120 & 120 \\
\hline$* *$ Correlation & is significant at the 0.01 level (2-tailed).
\end{tabular}

Selanjutnya dilakukan uji analisis regresi linier sederhana, uji ini digunakan untuk menguji pengaruh variabel kompetensi kepribadian widyaiswara (X) terhadap hasil belajar $(Y)$ peserta diklat prajabatan K1/K2. Pengambilan keputusan dalam uji regresi linear sederhana dapat mengacu pada dua hal, yakni: (a) Membandingkan nilai Sig. dengan nilai probabilitas 0,05 , jika nilai Sig. $<0,05$, artinya variabel $X$ berpengaruh terhadap variabel $Y$, atau jika nilai $S i g .>0,05$, artinya variabel $X$ tidak berpengaruh terhadap variabel $Y$; (b) Membandingkan nilai $t_{\text {hitung }}$ dengan $t_{\text {tabel }}$, jika nilai $t_{\text {hitung }}>t_{\text {tabel }}$ memiliki arti bahwa variabel $X$ berpengaruh terhadap variabel $Y$, atau jika nilai $t_{\text {hitung }}<t_{\text {tabel }}$ memiliki arti bahwa variabel $X$ tidak berpengaruh terhadap variabel $Y$.

Tabel 7. Hasil Koefisien Determinasi

\begin{tabular}{|c|c|c|c|c|}
\hline \multicolumn{5}{|c|}{ Model Summary ${ }^{b}$} \\
\hline Model & $R$ & $R$ Square & $\begin{array}{l}\text { Adjusted } \\
R \text { Square }\end{array}$ & $\begin{array}{l}\text { Std. Error of } \\
\text { the Estimate }\end{array}$ \\
\hline 1 &, $554^{\mathrm{a}}$ & ,307 & ,301 & 4,19659 \\
\hline
\end{tabular}

a. Predictors: (Constant), Kompetensi Kepribadian

b. Dependent Variable: Hasil Belajar

Dari Tabel 7 diketahui nilai koefisien korelasi $(R)$ yaitu 0,554 yang menunjukkan besarnya dari variabel kompetensi kepribadian widyaiswara terhadap hasil belajar. Nilai ini jika dikuadratkan akan menghasilkan nilai koefisien determinasi $(R$ square) yaitu 0,307. Koefisien determinasi bertujuan untuk mengetahui besarnya pengaruh variabel independen terhadap variabel dependen. Hasil koefisien determinasi tersebut di atas menginformasikan bahwa kompetensi kepribadian widyaiswara dapat mempengaruhi hasil belajar sebesar 30,7\% sedangkan sisanya dipegaruhi oleh variabel lain yang tidak menjadi fokus dalam penelitian ini.

Setelah diketahui bahwa kompetensi kepribadian mempengaruhi hasil belajar sebagaimana diketahui dari nilai koefisien determinasi di atas, kemudian dilakukan uji simultan dengan tujuan untuk mengetahui ada tidaknya pengaruh secara bersama-sama dari variabel independen terhadap variabel dependen. Uji ini terlihat pada output tabel ANOVA. Adanya pengaruh secara bersama-sama antar variabel independen jika nilai $F_{\text {hitung }}$ lebih dari $F_{\text {tabel }}$ dan signifikansi kurang dari tingkat signifikansi.

Tabel 8 menjelaskan bahwa nilai $F_{\text {hitung yaitu }} 52,152$ lebih dari $F_{\text {tabel yakni 3,92 }}$ dengan tingkat signifikansi 0,000 sehingga nilai $F_{\text {hitung }}$ lebih dari $F_{\text {tabel }}$ dan signifikansi kurang dari 0,05 , maka dapat diinformasikan bahwa pada tingkat 
kepercayaan $95 \%$ terdapat pengaruh simultan dari variabel kompetensi kepribadian widyaiswara terhadap hasil belajar.

Tabel 8. Hasil Uji Simultan (Uji F)

\begin{tabular}{lrrrrr}
\multicolumn{6}{c}{ ANOVA $^{\mathrm{a}}$} \\
\hline Model & $\begin{array}{c}\text { Sum of } \\
\text { Squares }\end{array}$ & $d f$ & $\begin{array}{c}\text { Mean } \\
\text { Square }\end{array}$ & $F$ & Sig. \\
1 & 918,461 & 1 & 918,461 & 52,152 &, $000^{\mathrm{b}}$ \\
\cline { 2 - 7 } & 2078,143 & 118 & 17,611 & & \\
\cline { 2 - 5 } & 2996,604 & 119 & & & \\
\hline
\end{tabular}

a. Dependent Variable: Hasil Belajar

b. Predictors: (Constant), Kompetensi Kepribadian

Kemudian dilakukan pengujian dengan uji $t$ yang digunakan untuk mengetahui ada tidaknya pengaruh variabel bebas terhadap variabel terikat yaitu variabel kompetensi kepribadian terhadap hasil belajar peserta diklat prajabatan K1/K2 secara parsial. Pengujian hipotesis dengan menggunakan uji parsial (uji $t$ ) dilakukan

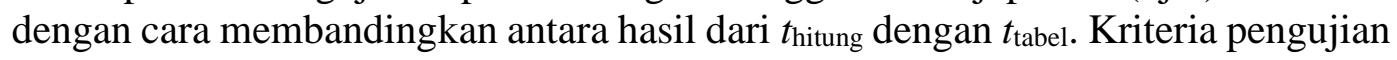
dengan menggunakan uji $t$ ini adalah $H_{\mathrm{o}}$ ditolak jika $t_{\text {hitung }}>t_{\text {tabel }}$ dan nilai Sig. $<0,05$.

Berikut akan disajikan Tabel 9, hasil pengujian hipotesis secara parsial (uji $t$ ) dengan menggunakan SPSS versi 23 for windows.

Tabel 9. Hasil Uji Parsial

Coefficients $^{\mathrm{a}}$

\begin{tabular}{|c|c|c|c|c|c|}
\hline \multirow[t]{2}{*}{ Model } & $\begin{array}{r}\text { Unstand } \\
\text { Coeffi }\end{array}$ & $\begin{array}{l}\text { dized } \\
\text { ents }\end{array}$ & \multirow{2}{*}{$\begin{array}{c}\text { Standardized } \\
\text { Coefficients } \\
\text { Beta }\end{array}$} & \multirow[t]{2}{*}{$t$} & \multirow[t]{2}{*}{ Sig. } \\
\hline & $B$ & $\begin{array}{l}\text { Std. } \\
\text { Error }\end{array}$ & & & \\
\hline 1 (Constant) & 60,459 & 1,887 & & 32,046 &, 000 \\
\hline $\begin{array}{l}\text { Kompetensi } \\
\text { Kepribadian }\end{array}$ & 3,076 & ,426 & ,554 & 7,222 & ,000 \\
\hline
\end{tabular}

a. Dependent Variable: Hasil Belajar

Dalam uji $t$ ini dilakukan pada derajat kebebasan $(n-k-1)$, di mana $n$ adalah jumlah responden dan $k$ adalah jumlah variabel. Untuk tingkat keyakinan yang digunakan adalah $95 \%$ atau $\alpha=5 \%$. 120-2-1=117 di mana $t_{\text {hitung }}=7,222$ sedangkan $t_{\text {tabel }}=1,980$. Berdasarkan hasil output di atas, variabel $X$ (kompetensi kepribadian widyaiswara) dengan $t_{\text {hitung }}$ sebesar 7,222, dengan demikian $t_{\text {hitung }}>t_{\text {tabel }}$ $(7,222>1,980)$ yang secara statistik, variabel $X$ (kompetensi kepribadian widyaiswara) mempengaruhi variabel $Y$ (hasil belajar) atau $H_{o}$ ditolak dan $H_{a}$ diterima, berarti terdapat pengaruh yang signifikan dari variabel kompetensi kepribadian widyaiswara terhadap hasil belajar.

\section{Pembahasan}

Berdasarkan hasil analisis data, diperoleh nilai koefisien korelasi 0,554 (koefisien mendekati angka 1), maka dapat diinformasikan bahwa hubungan antara kompetensi kepribadian widyaiswara dan hasil belajar memiliki korelasi yang cukup kuat. Angka koefisien positif menunjukkan hubungan positif, yaitu jika kompetensi meningkat maka hasil belajar juga akan meningkat. 
Hasil analisis tersebut menunjukkan kesamaan dengan hasil penelitian yang telah dilakukan oleh Muslim (2016) yang menyatakan bahwa terdapat pengaruh kompetensi kepribadian guru PAI dengan prestasi siswa dibuktikan koefisien korelasi positif sebesar 0,294. Hasil ini menunjukkan bahwa ada hubungan yang positif antara kompetensi kepribadian dengan prestasi belajar dan hubungannya sangat signifikan pada taraf signifikansi $5 \%$.

Berdasarkan hasil analisis diketahui nilai koefisien determinasi ( $R$ Square) sebesar 0,307, hal ini menginformasikan bahwa kompetensi kepribadian widyaiswara dapat mempengaruhi hasil belajar sebesar 30,7\% sedangkan sisanya dipegaruhi oleh variabel lain yang tidak menjadi fokus dalam penelitian ini.

Hasil penelitian ini searah dengan penelitian yang dilakukan oleh Purnomo \& Andriani (2019) Pengaruh kompetensi kepribadian guru terhadap hasil belajar didapatkan nilai $t_{\text {hitung }}>t_{\text {tabel }}(5,805>1,974)$. serta nilai koefisien korelasi $(R)$ variabel kompetensi kepribadian guru terhadap hasil belajar adalah 0,403. Sedangkan nilai koefisien determinasi $\left(R^{2}\right)$ adalah 0,162 . Artinya, sumbangan variabel kompetensi kepribadian guru terhadap hasil belajar adalah $16,2 \%$ dan sisanya sebesar $83,8 \%$ dipengaruhi oleh faktor lain yang tidak diteliti.

Hasil analisis dari penelitian ini diperoleh nilai $F_{\text {hitung }}$ sebesar 52,152 dengan nilai Sig. 0,000 yang memiliki arti bahwa nilai $F_{\text {hitung }}$ lebih dari $F_{\text {tabel }}$ yang sebesar 3,92 dan nilai signifikansi kurang dari 0,05, sehingga dapat diinformasikan bahwa terdapat pengaruh simultan dari variabel kompetensi kepribadian widyaiswara terhadap hasil belajar.

Hal ini sejalan dengan penelitian yang dilakukan oleh Suarjana \& Yintayani (2017) yang menyatakan bahwa berdasarkan hasil hitung uji- $F$ didapatkan nilai nilai $F$ sebesar 240,528 dengan Sig. 0,000. Hasil signifikansi $F(\operatorname{Sig} .=0,000)$ tersebut ternyata kurang dari 0,05 maka dapat diinterpretasikan bahwa kontribusi tersebut signifikan. Artinya kompetensi kepribadian dosen memiliki pengaruh yang signifikan terhadap prestasi belajar mahasiswa.

Diketahui nilai koefisien regresi 3,076 menunjukkan adanya pengaruh yang positif artinya semakin baik kompetensi kepribadian widyaiswara maka hasil belajar akan semakin tinggi begitu pula sebaliknya. Nilai koefisien ini juga mengartikan hasil belajar akan meningkat sebesar 3,076 satuan setiap kenaikan satu-satuan dari kompetensi kepribadian widyaiswara.

Hasil ini relevan dengan penelitian yang telah dilakukan oleh Arrosit (2018), yang menyatakan bahwa berdasarkan hasil analisis, maka persamaan garis regresi dapat dinyatakan sebagai berikut: $\hat{Y}=9.332+0,883 X_{1}$. Persamaan tersebut menunjukkan bahwa nilai koefisien regresi bernilai positif sebesar 0,883 yang berarti jika kompetensi kepribadian guru $\left(X_{1}\right)$ meningkat 1 point maka hasil belajar siswa $(Y)$ meningkat 0,883 .

Berdasarkan hasil pembahasan tersebut menginformasikan bahwa kompetensi kepribadian widyaiswara memiliki pengaruh yang signifikan terhadap hasil belajar peserta diklat prajabatan K1/K2 CPNS golongan III BPSDM Provinsi DKI Jakarta.

\section{KESIMPULAN}

Berdasarkan hasil penelitian diketahui bahwa kompetensi kerpibadian widyaiswara berpengaruh terhadap hasil belajar peserta diklat prajabatan. Hal ini terlihat dari hasil nilai koefisien determinasi 0,307 yang menunjukkan bahwa kompetensi 
kepribadian widyaiswara memberikan kontribusi sebesar 30,7\% dari hasil belajar, sedangkan sisanya dipegaruhi oleh variabel lain yang tidak menjadi fokus dalam penelitian ini.

Dari hasil analisis data diketahui pula bahwa nilai $F_{\text {hitung }}$ sebesar 52,152 dengan Sig. 0,000, sedangkan nilai $F_{\text {tabel }}$ sebesar 3,92, yang berarti bahwa nilai $F_{\text {hitung }}$ lebih dari $F_{\text {table }}$ dan nilai signifikansi kurang dari 0,05, maka dapat diiformasikan terdapat pengaruh yang simultan dari variabel kompetensi kepribadian widyaiswara terhadap hasil belajar.

Nilai koefisien regresi sebesar 3,076 dari hasil analisis data, menginformasikan adanya pengaruh yang positif dari kompetensi kepribadian widyaiswara terhadap hasil belajar. Artinya semakin baik kompetensi kepribadian widyaiswara maka hasil belajar akan semakin tinggi begitu pula sebaliknya. Nilai koefisien ini juga mengartikan hasil belajar akan meningkat sebesar 3,076 pada setiap kenaikan satusatuan dari kompetensi kepribadian widyaiswara.

\section{UCAPAN TERIMA KASIH}

Dalam kesempatan ini terucap terima kasih yang tak terhingga kepada Kepala Badan Pengembangan Sumber Daya Manusia (BPSDM) Provinsi DKI Jakarta yang telah memberikan kesempatan baik berupa waktu, data dan informasi kepada saya dalam menyelesaikan penelitian ini. Serta kepada sesama rekan-rekan widyaiswara Provinsi DKI Jakarta yang telah memberikan dukungan moril kepada saya agar terus semangat saya sampaikan juga ucapan terima kasih yang tak terhingga.

\section{REFERENSI}

Arikunto, S. (2013). Prosedur Penelitian Suatu Pendekatan Praktek. Jakarta: Rineka Cipta.

Arjita, U. A. (2019). Pengaruh Kompetensi Widyaiswara terhadap Prestasi Peserta Diklat pada Matadiklat Etika Publik di Pusdiklat BPS. Scholaria: Jurnal Pendidikan dan Kebudayaan, 9(1), 76-81. https://doi.org/10.24246/j.js.2019.v9.i1.p76-81

Arrosit, A. M. M. (2018). Pengaruh Kompetensi Kepribadian dan Kompetensi Pedagogik Guru terhadap Hasil Belajar Siswa Kelas X di SMA Bakti Ponorogo Tahun Pelajaran 2017/2018. Skripsi tidak diterbitkan, Jurusan Pendidikan Agama Islam Fakultas Tarbiyah dan Ilmu Keguruan Institut Agama Islam Negeri Ponorogo.

Dimyati,. \& Mudjiono. (2018). Belajar dan Pembelajaran. Jakarta: Rineka Cipta.

Hamzah, H. (2017). Kompetensi Widyaiswara dan Kualitas Diklat. Pembelajar: Jurnal Ilmu Pendidikan, Keguruan, dan Pembelajaran, 1(2), 111. https://doi.org/10.26858/pembelajar.v1i2.4865

Mansing, S. (2018). Pengaruh Kepribadian Guru PAI terhadap Hasil Belajar Siswa di Sekolah. IQRO: Journal of Islamic Education, 1(2), 121-128. https://doi.org/10.24256/iqro.v1i2.494

Moeheriono. (2012). Pengukuran Kinerja Berbasis Kompetensi. Jakarta: PT. Raja Grafindo Persada.

Muslim, A. A. (2016). Pengaruh Gaya Belajar, Pengelolaan Kelas dan Kompetensi Kepribadian Guru PAI terhadap Prestasi Belajar Siswa SMP Se-Kecamatan 
Dempet Bidang Studi PAI Tahun Pelajaran 2015/2016. Tesis tidak diterbitkan, Program Pasca Sarjana Magister Pendidikan Islam, Sekolah Tinggi Agama Negeri (STAIN) Kudus.

Ni'mah, K. (2014). Konsep Kompetensi Kepribadian Guru PAI (Telaah Kitab Ta'līm al-Muta'allim Karya az-Zarnuji dan Kitab Adāb al- 'Ālim wa alMuta'allim Karya KH. Hasyim Asy’ari). Jurnal Pendidikan Agama Islam, 11(1), 79-94.

Peraturan Kepala LAN-RI. No. 10. (2015). Tentang Penyelenggaraan Diklat Prajabatan CPNS Golongan I, II dan III yang diangkat dari tenaga honorer K1/K2. Jakarta: Lembaga Administrasi Negara RI.

Peraturan Kepala LAN No. 5. (2008). Tentang Standar Kompetensi Widyaiswara. Jakarta: Lembaga Administrasi Negara RI.

PermenPAN-RB No. 22. (2014). Tentang Jabatan Fungsional Widyaiswara dan Angka Kreditnya. Jakarta: KemenPAN-RB Republik Indonesia.

Pitra, D. M. I. (2019). Pengaruh Kompetensi Kepribadian Guru terhadap Hasil Belajar PAI Siswa Kelas VIII SMPN 02 Seluma. Skripsi tidak diterbitkan, Program Studi Pendidikan Agama Islam Jurusan Tarbiyah Fakultas Tarbiyah Dan Tadris Institut Agama Islam Negeri (IAIN) Bengkulu.

Purnomo, A. P., \& Andriani, L. (2019). Pengaruh Kompetensi Kepribadian Guru dan Fasilitas Belajar terhadap Hasil Belajar Siswa pada Mata Pelajaran Ekonomi Kelas XI IPS SMA Negeri 8 Kota Jambi. Scientific Journals of Economic Education, 3(1), 11-21.

Sartika, S. H., Dahlan, D., \& Waspada, I. (2018). Kompetensi Guru dan Motivasi Belajar Siswa terhadap Hasil Belajar melalui Kebiasaan Belajar Siswa. Manajerial: Jurnal Manajemen dan Sistem Informasi, 3(4), 39-51.

Suarjana, A. A. G. M., \& Yintayani, N. N. (2017). Pengaruh Kompetensi Dosen terhadap Prestasi Belajar Mahasiswa pada Jurusan Akuntansi Politeknik Negeri Bali. Jurnal Bisnis dan Kewirausahaan, 13(2), 87-96.

Sugiyono. (2017). Metode Penelitian Kuantitatif dan Kualitatif dan R\&D. Bandung: Alfabeta.

Sumantri, B. A., Abdullah, I., \& Nurlaila. (2019). Pengaruh Kompetensi Kepribadian Guru terhadap Prestasi Belajar Siswa di MTS Ar-Riyadh 13 Ulu Palembang. Jurnal PAI Raden Fatah, 1(3), 294-309.

Sutopo, A. W. (2019). Peningkatan Hasil Belajar Matematika Materi Trigonometri Melalui Model Pembelajaran Kooperatif Tipe Teams Games Tournament (TGT) di XI-IPA 2 SMA Negeri 9 Jakarta. Jurnal Ilmu Pendidikan (JIP) STKIP Kusuma Negara, 2(2), 15-26.

Uno, H. B. (2008). Model Pembelajaran. Yogyakarta: Andi Offset.

UU No. 14. (2005). Tentang Guru dan Dosen. Jakarta: Sekretariat Negara RI. 